\title{
Low-temperature, fluid-driven resetting of titanite following ultrahigh-temperature metamorphism in Madagascar
}

\author{
ROBERT HOLDER ${ }^{1}$ AND BRADLEY R HACKER ${ }^{2}$ \\ ${ }^{1}$ University of Michigan \\ ${ }^{2}$ University of California, Santa Barbara \\ Presenting Author: roholder@umich.edu
}

LA-ICP-MS U-Pb dates and EPMA trace-element maps of titanite were collected from granulite-facies calc-silicate gneisses of southern Madagascar (peak $T: 750-950^{\circ} \mathrm{C}$ ) to evaluate how titanite responds to high-temperature metamorphism, cooling, and retrogression. Fluid-mediated replacement of precursor titanite by titanite of different composition (interface-coupled dissolution-precipitation, ICDR) - not diffusion-was the primary mechanism by which titanite was reset following highgrade metamorphism. Comparison of titanite U-Pb dates (530$490 \mathrm{Ma}$ ) with independent petrology and thermochronology indicates that the alteration occurred at temperatures as low as 300-500 ${ }^{\circ} \mathrm{C}$. Apparent $\mathrm{Zr}$ temperatures (temperatures calculated assuming titanite-quartz-zircon equilibrium) in altered titanite are less than or equal to the metamorphic peak, but higher than the inferred alteration temperature, implying that $\mathrm{Zr}$ was removed, but that titanite-quartz-zircon equilibrium was not achieved during alteration. Although evidence for ICDR was observed over a region of $\sim 100 \mathrm{~km}$, differences in $\mathrm{U}-\mathrm{Pb}$ dates among samples, and even among titanite grains in the same thin section suggest that alteration was highly localized at any given time.

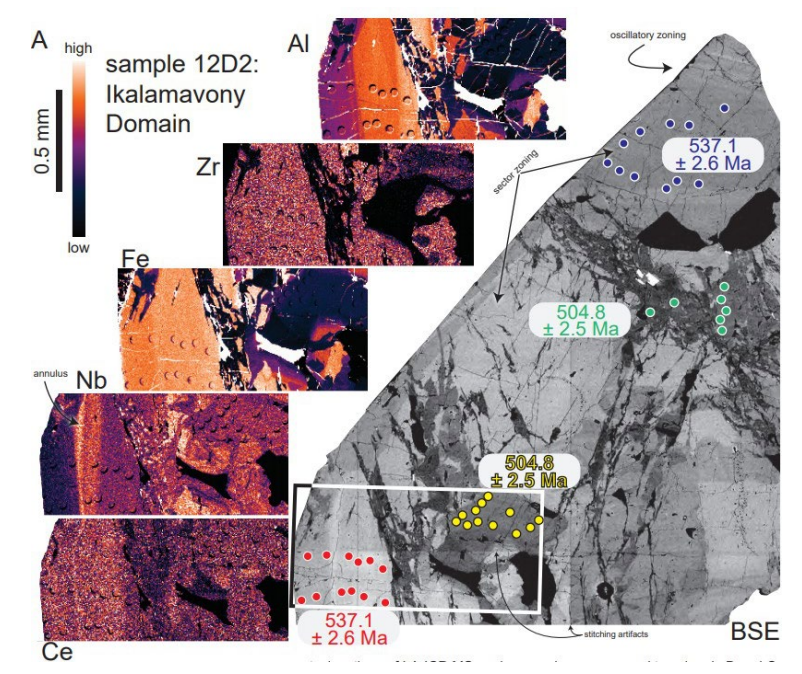

